\title{
O JABUTI E A ANTA: POVO MUNDURUKU, HIDRELÉTRICA, CONFLITO E CONSULTA PRÉVIA NA BACIA DO RIO TAPAJÓS
}

Rodrigo Magalhães de Oliveira (D)

Ministério Público Federal I Santarém - PA - Brasil 
O artigo apresenta uma análise etnográfica documental dos múltiplos conflitos envolvendo o povo Munduruku e o governo federal, a partir da tentativa de implantação da Usina Hidrelétrica São Luiz do Tapajós, enfatizando o embate quanto à aplicação situacional do direito à consulta prévia, livre e informada. Tendo como base a história indígena que opõe o jabuti e a anta, procuro demonstrar as discursividades conflitantes, as resistências e os interesses em disputa na implantação deste projeto, bem como explicitar como os agentes envolvidos mobilizam diferentes sentidos para o dispositivo legal que é o direito à consulta prévia.

Palavras-chave: Munduruku; governo federal; consulta prévia; aplicação situacional

\section{THE LAND TURTLE AND THE TAPIR: MUNDURUKU INDIGENOUS PEOPLE, HYDROELECTRIC, CONFLICT AND PRIOR CONSULTATION ON THE TAPAJÓS RIVER BASIN}

The article presents a documentary ethnographic analysis of the multiple conflicts involving the Munduruku people and the federal government, from the attempt to implement the São Luiz do Tapajós Hydroelectric Power Plant, emphasizing the clash regarding the situational application of the right to prior, free and informed consultation. Based on the indigenous history that opposes the jabuti and the tapir, I seek to demonstrate the conflicting discursivities, resistances and interests in dispute in the implementation of this project, as well as to explain how the agents involved mobilize different meanings for the legal device that is the right to prior consultation.

Keywords: Munduruku; federal government; prior consultation; situational application.

\section{EL JABOTÍ Y EL TAPIR: PUEBLO INDÍGENA MUNDURUKU, HIDROELÉCTRICA, CONFLICTO Y CONSULTA PREVIA EN LA CUENCA DEL RÍO TAPAJÓS}

El artículo presenta un análisis documental etnográfico de los múltiples conflictos que involucran al pueblo Munduruku y al gobierno federal, desde el intento de implementar la Central Hidroeléctrica São Luiz do Tapajós, enfatizando el choque con respecto a la aplicación situacional del derecho a consulta previa, libre e informada. Basado en la historia indígena que se opone al jabotí y al tapir, trato de demostrar los discursos, resistencias e intereses en disputa en la implementación de este proyecto, así como explicar cómo los agentes involucrados movilizan diferentes significados para el dispositivo legal que es el derecho a consulta previa.

Palabras clave: Munduruku; gobierno federal; consulta 


\section{INTRODUÇÃO}

O jabuti está muito presente na cosmologia munduruku. $\mathrm{O}$ animal inspira grafismos e pinturas corporais e é protagonista de muitos mitos e histórias. Usualmente associado à fragilidade e à lentidão no senso comum, para os Munduruku o animal é sinônimo de paciência, de sabedoria e de força. Com seus peculiares atributos, é capaz de vencer uma enorme anta e até mesmo o animal mais temido da floresta: a onça pintada. Para compensar sua desvantagem física - de porte e de velocidade -, o pequeno animal se vale de sua paciência e astúcia. As epopeias do jabuti se realizam de diferentes modos, a depender do contexto e do contador, por exemplo, com o jabuti descrevendo movimentos de arco para cansar ou surpreender a onça.

Para vencer a anta, o jabuti se aproxima com discrição e morde seu aparelho reprodutor, ferindo-a mortalmente:

Ao amanhecer, os animais entram na floresta para comer suas frutas preferidas. Na época do buriti, os animais vão até os buritizais para comer as frutinhas que caem ao chão. O jabuti, muito sabido, foi o primeiro a chegar. Começou a comer, comer, deixando só os caroços.

A anta chegou atrasada e viu vários caroços de buriti no chão, todos roídos. Muito brava, a anta perguntou para vários animais quem tinha comido o seu buriti. Os animais responderam que tinham comido um pouco, mas que um animal tinha chegado bem cedinho no buritizal e ficado comendo até tarde. Enquanto isso, o jabuti continuou comendo, saboreando, roendo até o caroço do buriti.

A anta pegou o jabuti, pisou, pisou, e falou "agora vou matar você, jabuti, você não vai mais sobreviver para comer meu buriti”, depois foi embora. E o jabuti ficou lá enterrado, bem escondido e quieto. Começou a tirar a terra, bem devagarzinho, até conseguir sair.

Ficou caçando a anta, queria se vingar. Perguntou para vários dos animais onde é que estava a anta. Procurou bastante, não encontrou, mas não perdeu a esperança, até que finalmente conseguiu encontrar.

A anta corre muito rápido, consegue entrar na água, mas ela é alta e o jabuti é baixinho. O jabuti foi com bastante calma, sem dizer nada e sem ser visto, e mordeu o "saco" da anta, que foi ao chão e ficou gemendo de dor: "você não pode me enterrar só por causa da comida. Você podia pedir por favor pra gente dividir a comida, não precisava me enterrar”. E a anta morreu (A. Korap, comunicação pessoal, Santarém, 2020).

As entrelinhas da saga do jabuti contra a anta encorajam: os "pequenos" podem vencer os "grandes", desde que sejam espertos e que se movimentem estrategicamente. Com o anúncio do projeto da Usina Hidrelétrica (UHE) de São Luiz do Tapajós, a história passou a ser acionada pelos Munduruku (o jabuti) para narrar sua resistência ao empreendimento que o governo federal (a anta) pretende implantar na bacia do rio Tapajós.

O artigo ${ }^{1}$ apresenta uma etnografia documental

$1 \mathrm{O}$ artigo é resultado de minha pesquisa de mestrado, desenvolvida durante os anos de 2014 e 2016, tendo sido revisto e atualizado com informações ulteriores à defesa da dissertação (Oliveira 2016). 
(Vianna 2014) $)^{2}$ do conflito travado entre os Munduruku e o governo em torno da UHE de São Luiz do Tapajós, nos moldes propostos por Little (2006), tendo como fio condutor a reivindicação dos indígenas pela adequada aplicação do direito à consulta prévia, livre e informada.

A propósito, este direito, previsto na Convenção $\mathrm{n}^{\circ} .169$ da Organização Internacional do Trabalho de 1989, afirma que os "povos indígenas e tribais" devem ser consultados pelos governos sempre que forem previstas medidas administrativas ou legislativas suscetíveis de afetá-los diretamente (OIT 1989:Artigo 6º). A Convenção foi incorporada às leis brasileiras e seu cumprimento se tornou obrigatório em junho de 2003 (Brasil, Supremo Tribunal Federal 2006).

Discuto alguns elementos imprescindíveis à compreensão da etnografia, identificando os diferentes agentes envolvidos, o ambiente da contenda, que tipo de projeto está produzindo o conflito, quais são os impactos desse projeto, as interações e a distribuição de poder entre os agentes (Little 2006). Descrevo, na sequência, os principais episódios da resistência dos Munduruku aos aproveitamentos hidrelétricos, com ênfase às interações e às múltiplas táticas e estratégias mobilizadas pelos agentes, em especial a recorrente demanda pela garantia do direito à consulta prévia, confrontando os discursos públicos a esse respeito e documentando etnograficamente a história do conflito (Little 2006:93).

No que tange ao direito à consulta, parto do pressuposto de que as normas jurídicas estabelecidas "constituem um corpo de premissas que ordenam a vida social, porém que se elaboram como um dever ser" (Guizardi 2012:26). O consenso em relação à norma no plano macrossocial convive com diferentes formas de interpretá-la e aplicála no plano microssocial (Guizardi 2012:27). O uso concreto das normas exige a adaptação situacional de seu conteúdo, pois a aplicação da norma produz sua ressignificação em uma situação histórica e social específica (Gluckman 2009; Guizardi 2012:27). Nesse sentido, em que pesem as assimetrias simbólicas, econômicas e políticas existentes, a aplicação situacional das normas é produto do embate entre os sentidos que os diferentes grupos em conflito lhe atribuem (Guizardi 2012:32).

Busco apresentar uma abordagem descritiva,

2 Acerca da etnografia documental, Vianna (2014:47) defende que "levar a sério os documentos como peças etnográficas implica tomá-los como construtores da realidade tanto por aquilo que produzem na situação da qual fazem parte como fabricam um 'processo' como sequência de atos no tempo, ocorrendo em condições específicas e com múltiplos e desiguais atores e autores - quanto por aquilo que conscientemente sedimentam" e, nesse sentido, a precaução do etnógrafo deve ser "levar a sério o que nos é mostrado, o modo como essa exibição se ordena, a multiplicidade de vozes e mãos presentes na sua confecção, sua dimensão material, seu lugar em cadeias de outros documentos e ações, suas lacunas e silêncios" (2014:48). 
inclusive oferecendo transcrições dos discursos públicos do governo e dos Munduruku, para explicitar o embate que estes agentes mantêm sobre a aplicação situacional do direito à consulta prévia. Com isso, não quero dizer que o conflito para significar o direito à consulta prévia possa ser lido como diferentes interpretações possíveis de um mesmo dispositivo jurídico. A etnografia evidenciará que as práticas governamentais intentaram neutralizar a efetiva participação dos indígenas e, em muitos casos, violaram frontalmente os parâmetros legais que o Estado está obrigado a respeitar.

O objetivo é, de um lado, explicitar que o conflito em torno do empreendimento e de seus impactos socioambientais também assumiu a dimensão de um intrincado embate jurídico quanto à aplicação situacional do direito à consulta prévia; de outro, demonstrar de que forma os Munduruku utilizaram estrategicamente o direito à consulta prévia para defender a integridade de seus territórios e do rio Tapajós.

Embora tenha atuado junto ao povo Munduruku em parte dos episódios descritos, em respeito à decisão dos indígenas acerca de quais informações devam ser publicizadas ou não3, e considerando que interessa particularmente a este manuscrito analisar os discursos públicos construídos pelos indígenas, faço referência no texto apenas às informações obtidas por meio de fontes documentais, ainda que minhas observações em campo inspirem inevitavelmente as reflexões.

Ainda que os Munduruku e o "governo federal" sejam agentes coletivos e, portanto, múltiplos e diversos, os documentos analisados expressam entendimentos coletivos ou oficiais, no sentido de que publicizam discursos construídos de acordo com a organização política e jurídica de cada um desses agentes. No caso do governo, utilizo entrevistas de autoridades do alto escalão, notas, releases, bem como atos e documentos judiciais e administrativos (processos judiciais, relatórios, memorandos, pareceres técnicos e ofícios). No caso dos Munduruku, utilizo as cartas, que são documentos discutidos, construídos e aprovados coletivamente, em especial no âmbito das assembleias gerais e do Movimento Iperěg Ayũ. Mesmo as entrevistas analisadas não expressam unicamente a posição individual do entrevistado, pois são concedidas por lideranças ou representantes indicados pelos indígenas.

\section{A ANTA}

A UHE São Luiz do Tapajós está projetada para o médio rio Tapajós, trezentos e trinta

3 Com o propósito de obter a suspensão do licenciamento ambiental da hidrelétrica, que avançava sem consulta prévia, os Munduruku decidiram proibir a realização de pesquisas com dados empíricos primários, de modo a evitar que essas pesquisas fossem indevidamente utilizadas pelo governo federal para elaboração do Estudo de Componente Indígena. 
quilômetros acima da foz no rio Amazonas, sessenta e cinco quilômetros à montante da zona urbana do município de Itaituba, estado do Pará. Com um reservatório estimado em 729 quilômetros quadrados e barramento de oito quilômetros de extensão, prevê uma geração nominal média de energia de 4.012MW, com valor estimado em trinta bilhões de reais.

Maior dentre as quarenta e três hidrelétricas previstas para a bacia do rio Tapajós (Fearnside 2015), a UHE São Luiz do Tapajós, se construída, impactaria o povo indígena Munduruku e dezenas de comunidades tradicionais ribeirinhas ${ }^{4}$, bem como onze unidades de conservação, que resguardam parte dos ecossistemas com maior biodiversidade do planeta, em uma região de alta relevância ecológica para a conservação do bioma amazônico, segundo o próprio Estudo de Impacto Ambiental. O governo federal também prevê a instalação de outras duas mega-hidrelétricas no curso principal do rio Tapajós: as UHE Jatobá e Chacoarão, ambas teriam impactos diretos sobre os territórios dos Munduruku.

O Estudo do Componente Indígena ${ }^{5}$ previu o alagamento de $7 \%$ da superfície da Terra Indígena Sawré Muybu (ou Daje Kapap Eypi, como se referem os indígenas) - principal loci do conflito -, o que resultaria na remoção compulsória de ao menos três aldeias situadas às margens do rio Tapajós (Sawré Muybu, Dace Watpu e Karo Muybu), o que é vedado pelo artigo 231 , §5 da Constituição brasileira. Ao menos dois locais sagrados para os Munduruku serão irreversivelmente impactados: a "Travessia dos Porcos" (daí o nome do território Daje Kapap Eypi, que significa "por onde os porcos passaram") e a "Garganta do Diabo" (Fearnside 2015:23-24). Há previsão, ainda, de diversos outros impactos diretos e indiretos.

Sublinhe-se que a Terra Indígena Sawré Muybu, à época da elaboração do Estudo do Componente Indígena, estava "em identificação" quanto ao andamento do processo administrativo de demarcação, mais precisamente, aguardando aprovação e publicação do Relatório Circunstanciado de Identificação e Delimitação pela Fundação Nacional do Índio (Funai). Em razão de este território estar no epicentro do conflito e da percepção de que o reconhecimento oficial traria

4 Embora as comunidades tradicionais também sejam sujeitos do direito à consulta prévia, este artigo não se dedica ao seu estudo em específico.

5 Segundo as normas brasileiras relativas ao licenciamento ambiental, deverá ser elaborado Estudo do Componente Indígena quando o projeto previsto puder causar impacto sobre povos indígenas. Nesse caso, a Fundação Nacional do Índio (Funai) encaminha um Termo de Referência ao órgão licenciador (espécie de checklist determinando os pontos que devem constar no estudo), que deve exigir do empreendedor a confecção do referido estudo. Cabe ainda à Funai avaliar se os estudos apresentados estão em conformidade com o Termo de Referência e se o empreendimento é viável em relação aos povos indígenas. 
obstáculos jurídicos ao projeto da hidrelétrica, a Funai protelou ao máximo sua publicação, sem que houvesse justificativa técnica, como se verá adiante.

A hidrelétrica é parte de um projeto mais amplo de transformação previsto para região. Se outrora a bacia do Tapajós despertou cobiça em função dos ciclos da borracha (final do século XIX e início do XX), do garimpo de ouro (décadas de 1970 e 1980) e da construção de estradas (Cuiabá-Santarém BR-163 e Transamazônica - BR-230), atualmente também passou a ser alvo de um ambicioso plano logístico e de infraestrutura. Graças à localização geográfica privilegiada e ao potencial minerário e florestal, setores públicos e privados nutrem a expectativa de que a região seja consolidada como corredor de escoamento de commodities agrícolas produzidas no Centro-Oeste e em fonte de energia abundante para os empreendimentos minerários que se quer instalar na área.

Verifica-se, assim, que o projeto da UHE São Luiz do Tapajós está imerso em uma teia de grandes interesses públicos e privados e é passo decisivo de uma agenda de transformação aguda que se pretende impor à região. O sentido da contextualização que aqui se apresenta é dar mostras da magnitude e da multiplicidade de interesses por trás da obra e também visibilizar a dimensão das assimetrias que atravessam o processo de consulta prévia, livre e informada, que o governo federal deveria conduzir.

Não à toa a hidrelétrica e o governo federal foram comparados à anta pelos indígenas. Conscientes destas assimetrias, os Munduruku sabiam que o governo federal não hesitaria em fazer uso da força e da violência estatal para tirar o projeto do papel, inclusive mediante a violação de direitos garantidos. Por isso, tal como o jabuti, os indígenas sabiam que precisavam se movimentar estrategicamente.

\section{0 JABUTI}

O povo indígena Munduruku se autodenomina We Dji Nyo, ou “nós, as pessoas” (R. Silva 2014:2). A designação Munduruku, maneira como o grupo é conhecido pela sociedade envolvente, significa formiga vermelha e teria sido atribuída pelos indígenas Parintintim, em alusão à forma como os Munduruku guerreavam com as etnias rivais $(\mathrm{R}$. Silva 2014:2). São muitas as referências históricas ao espírito guerreiro do povo Munduruku. Em carta datada de 1724, o rei de Portugal, dom João V, referiu-se à "bárbara nação" que habitava as primeiras corredeiras do rio Tapajós (Arnaud 1974:6). A resistência dos Munduruku à colonização rendeu-lhes fama, entre cronistas, missionários e viajantes, de bárbaros e cruéis (Coudreau 1977 [1896]; Tocantins 1877; Von Ihering 1907), em 
que pese a forma de descrever estes indígenas ter se modificado de acordo com a relação que estabeleciam com os portugueses.

Durante o século XVIII, foram tidos pela Coroa portuguesa como inimigos irreconciliáveis, tanto que a Carta Régia de 1798, que garantiu liberdade formal aos indígenas, manteve a possibilidade de escravização dos Munduruku (Cunha \&Farage 1987). Há registros de ataques protagonizados pelos Munduruku às cidades de Santarém (1780) e Gurupá (1784), e a etnias consideradas rivais, os Mura, os Parintintim e os Apiaká (Arnaud 1974:16). Durante ou após as expedições guerreiras, os Munduruku cortavam as cabeças de seus inimigos e as mumificavam (pariná), o que lhes garantia prestígio e vitalidade (Coudreau 1977 [1896]; Von Ihering 1907).

Embora as guerras e os conflitos interétnicos precedam a colonização, com a expansão colonial, eles se intensificaram e adquiriram nova conotação diante do progressivo confinamento territorial a que os povos indígenas foram submetidos. De todo modo, a capacidade guerreira proporcionou aos Munduruku o domínio territorial da bacia do rio Tapajós no início do século XIX, região denominada por Aires de Casal (1976 [1817]) de Mundurukânia, território limitado ao norte pelo Amazonas, ao sul pelo Juruena, a leste pelo Tapajós e a oeste pelo Madeira. Muitas referências históricas indicavam o predomínio dos Munduruku nesta região, ainda que densamente povoada por diversos grupos indígenas (Menéndez 1992). Com os ciclos da borracha (final do século XIX e início do XX), que vitimaram e escravizaram muitos indígenas, os Munduruku se dispersaram ao longo dos interflúvios dos rios Madeira, Tapajós e Xingu, constituindo diferentes grupos.

Os Munduruku que vêm encampando a luta contra a UHE São Luiz do Tapajós, e a que se refere esta etnografia, estão no médio e no alto rio Tapajós. Os grupos munduruku situados no médio e alto Tapajós são conformados por uma população de 13.103 pessoas, em cerca de 130 aldeias (ECI 2014). Na região do médio Tapajós, os indígenas estão nas proximidades do rio Jamanxim (Terras Indígenas Sawré Muybu e Sawré Bap’in, em identificação) e na cidade de Itaituba (Reservas Indígenas Praia do Mangue e Praia do Índio). No alto, estão na calha principal do rio Tapajós e do Teles Pires, e afluentes à margem direita: rios das Tropas, Kabitutu, Cururu, Crepori e Cadariri (Terras Indígenas Sai Cinza, Munduruku, Kayabi e Apiaká-Kayabi).

O médio e o alto Tapajós estão separados por longas distâncias e por barreiras naturais (corredeiras, cachoeiras, montanhas e florestas densas). Os grupos que habitam cada trecho costumam resolver internamente os problemas mais 
locais, como a falta de posto de saúde nas aldeias ou questões relativas a saneamento e educação. Quando entram em cena os "grandes projetos", como no momento em que o governo anuncia a intenção de construir os projetos hidrelétricos, as relações entre os grupos do médio e do alto se estreitam e as decisões são tomadas por este grupo mais amplo, conforme se explicitará adiante.

\section{0 HISTÓRICO DO CONFLITO: A}

\section{APLICAÇÃO SITUACIONAL DO DIREITO À CONSULTA PRÉVIA}

A consulta prévia, livre e informada referente à UHE São Luiz do Tapajós é objeto de uma longa trajetória de reivindicação protagonizada pelo povo Munduruku. Os primeiros passos foram dados à época do avanço da construção do complexo hidrelétrico do rio Teles Pires, um dos formadores do Tapajós, especificamente as UHE Teles Pires e São Manoel. Em 2009, reunidos na aldeia Missão São Francisco, no rio Cururu, os Munduruku divulgaram carta para exigir a paralisação de todos os empreendimentos planejados ou em construção na bacia hidrográfica onde vivem: "Não somos peixes para morar no fundo do rio, nem pássaros, nem macacos para morar nos galhos das árvores. Nos deixem em paz” (Carta do povo Munduruku ao Governo Federal 2009).

No ano seguinte, em 22 de novembro de 2010, cerca de quinhentos Munduruku ocuparam a audiência pública da UHE Teles Pires, sediada na cidade de Alta Floresta, estado de Mato Grosso. Durante a audiência, acompanhada de perto por dezenas de oficiais da Força Nacional de Segurança Pública (FNSP), os indígenas manifestaram sua oposição ao empreendimento e questionaram os representantes do governo federal se, ainda assim, levariam o projeto adiante. Estes disseram que não caberia aos indígenas a decisão.

Em outubro de 2011, os Kayabi e os Munduruku retiveram na aldeia Cururuzinho, à margem do rio Teles Pires, no interior da terra indígena Kayabi, sete funcionários da Empresa de Pesquisa Energética e da Funai, que realizavam estudos técnicos para o complexo de usinas hidrelétricas na bacia do Tapajós. Os indígenas exigiram a homologação da Terra Indígena Kayabi e a paralisação do licenciamento da UHE São Manoel (C. Silva 2011).

6 "Não somos peixes para morar no fundo do rio, nem pássaros, nem macacos para morar nos galhos das árvores. Nos deixem em paz. Não façam essas coisas ruins. Essas barragens vão trazer destruição e morte, desrespeito e crime ambiental, por isso não aceitamos a construção das barragens. Se o governo não desistir do seu plano de barragens, já estamos unidos e preparados com mais de 1.000 (mil) guerreiros, incluindo as várias etnias e não índios. Nós, etnia Munduruku, queremos mostrar agora como acontecia com os nossos antepassados e os brancos (pariwat) quando em guerra, cortando a cabeça, como vocês veem na capa deste documento. Já moramos mais de 500 anos dentro da floresta amazônica, nunca pensamos destruir, porque nossa mata e nossa terra são nossa mãe. Portanto não destruam o que guardamos com tanto carinho" (Carta do povo Munduruku ao Governo Federal 2009). 
Representantes do governo federal foram até a aldeia para negociar a liberação dos técnicos, mas não houve comprometimento com as pautas reivindicadas pelos indígenas (Palmquist 2016).

Em dezembro do mesmo ano, as três etnias afetadas pelas UHE no rio Teles Pires (os Munduruku, Kayabi e Apiaká) divulgaram um manifesto contra a destruição de lugares sagrados e a morte de peixes, exigindo que seu direito à consulta prévia, livre e informada fosse respeitado (Manifesto... 2011).

O Ministério Público Federal (MPF) - importante aliado dos Munduruku na reivindicação por direitos frente aos barramentos - atuou judicialmente para garantir o direito à consulta nos casos das UHE São Manoel e Teles Pires (Brasil, Ministério Público Federal 2012b, 2013a), porém o governo fez uso de um instrumento processual controverso para tornar sem efeito as decisões judiciais favoráveis aos indígenas ${ }^{7}$. Ao cabo, as iniciativas não surtiram efeito e ambas as barragens foram construídas sem consulta.

Nesse contexto de crescente tensionamento, o governo federal avançou com os planos de licenciar a UHE São Luiz do Tapajós. Em 2011, o projeto foi eleito prioritário para o planejamento energético brasileiro (Brasil, Conselho Nacional de Pesquisa Energética 2011). Considerando o local onde a hidrelétrica seria implantada, sabia-se desde o princípio que afetaria diretamente o povo Munduruku e, consequentemente, o governo tinha ciência da obrigação de consultá-lo previamente.

Não obstante, e repetindo o proceder das barragens do Teles Pires, o Instituto Brasileiro de Meio Ambiente e Recursos Naturais Renováveis (Ibama) concedeu sucessivas autorizações que permitiam a circulação, no território indígena, dos técnicos responsáveis pela elaboração dos estudos de impacto ambiental, sem qualquer diálogo prévio, o que foi denunciado pelos Munduruku (Carta das Lideranças ao Ministério de Minas e Energia/Brasília 2012).

Os Munduruku criaram, em julho de 2012, um movimento que futuramente viria a ser chamado de Movimento Iperěg Ayũ ("o povo que sabe se defender" [Loures 2017:2]) e que busca articular a luta em defesa do território e contra as barragens. Desde então, o movimento vem protagonizando ações diretas, parcerias com outros povos - em especial os beiradeiros de Montanha e Mangabal - e organizações, bem como a interlocução com os órgãos estatais.

7 A Suspensão de Liminar e Antecipação de Tutela (SLAT) é um instrumento judicial que permite ao presidente de um tribunal suspender a execução de sentenças e liminares assinadas por juízes de instância inferior para evitar grave lesão à ordem, à saúde, à segurança e à economia públicas (Lei no 8.437/1992, artigo $4^{\circ}$ ). Para uma leitura mais aprofundada acerca do tema, ver Oliveira \& Vieira (2016). 
Em setembro de 2012, os Munduruku abordaram novamente uma equipe de técnicos responsáveis pelos estudos, por estarem coletando materiais na área sem autorização (Brasil, Eletrobras 2012). O cenário que estava se desenhando demandou a intervenção do MPF, que acionou a justiça para que a consulta prévia não fosse preterida para momento posterior à elaboração dos estudos ambientais e que precedesse a toda e qualquer autorização para a construção da usina. A Justiça Federal em Santarém julgou o pedido parcialmente favorável, compreendendo não ser lícito emitir licença ambiental antes de realizada a consulta, no entanto, não determinou a paralisação do licenciamento.

Contrariando o pedido do MPF, a decisão estabeleceu quais grupos deveriam ser consultados a partir de suas localizações geográficas em relação ao empreendimento, ou seja, não determinou que a consulta se dirigisse aos Munduruku como um todo, mas às “comunidades indígenas Andirá-Marau [nome da terra indígena ocupada tradicionalmente pelos Sateré-Mawé], Praia do Mangue, Praia do Índio, Pimental [Sawré Muybu], km 43 [Sawré Apompu], São Luiz [Sawré Juybu]” (Brasil 2012). Segundo a decisão, a consulta deveria se restringir aos Munduruku do médio Tapajós (região das aldeias citadas), desrespeitando a organização social e política dos indígenas, que necessariamente inclui a participação do alto Tapajós.

O juiz atribuiu ao MPF a responsabilidade pela indicação das "lideranças aptas e legitimadas para representá-las [as comunidades indígenas], locais e datas de sua audiência (sendo que neste último caso podem ser ajustadas por acordo entre as partes)" (Brasil 2012). Ao final, a decisão admite que a consulta seja excepcionada caso o governo demonstre que "os índios frustraram ou se recusaram a opinar sobre o aproveitamento hídrico discutido" (Brasil 2012). Segundo a própria Convenção $\mathrm{n}^{\circ} .169$, cabe aos próprios indígenas a indicação de sua forma de representação e participação, e não ao Ministério Público.

O próprio MPF recorreu ao tribunal, que ordenou a suspensão imediata do licenciamento da UHE São Luiz do Tapajós (Brasil, Tribunal Regional Federal $1^{a}$ Região 2013). O governo fez uso novamente do instrumento processual controverso acima referido e o ministro presidente do Superior Tribunal de Justiça permitiu a continuidade do licenciamento, por compreender que "interromper o planejamento do Governo destinado ao setor energético do país, estratégico para o 
desenvolvimento da nação, causa grave lesão à ordem pública”. Apesar disso, o ministro ratificou a impossibilidade de concessão de qualquer licença enquanto não fosse efetuada consulta aos povos indígenas que pudessem ser afetados pelo projeto (Brasil, Superior Tribunal de Justiça 2013).

A decisão foi mantida e não cabe mais recursos, o que significa que, ressalvada a hipótese de o processo judicial sofrer uma reviravolta (por exemplo, descumprimento deliberado da decisão judicial), o direito à consulta prévia se impõe. Diante disso, os embates se concentraram no modo como a consulta deveria ser concretizada.

Em fevereiro de 2013, os Munduruku iniciaram um ciclo de constantes viagens a Brasília, para pressionar o governo federal a respeitar o direito à consulta e demarcar a terra indígena Sawré Muybu. Na ocasião, reuniram-se com Gilberto Carvalho, então ministro da Secretaria Geral da Presidência da República, órgão do governo federal que assumiu a responsabilidade de conduzir o processo de consulta:

Vocês têm duas opções: uma delas

\begin{abstract}
é inteligente: é dizer ok, nós vamos acompanhar, vamos exigir direitos nossos, vamos exigir preservação disso e disso e benefícios para nós. A outra é dizer não. Isso vai virar, infelizmente, uma coisa muito triste, e vai prejudicar muito a todos, ao governo, mas também a vocês. A hidrelétrica a gente não faz porque a gente quer, (mas) porque o país precisa - explicava Gilberto [Carvalho] (Alencastro \& Souza 2013).
\end{abstract}

Os Munduruku não recuaram e se mantiveram firmes na estratégia de impedir o trabalho dos técnicos responsáveis pelos estudos ambientais enquanto não fosse iniciada a consulta. Em vez de abrir finalmente o diálogo, o governo federal optou por levar a cabo uma estratégia de militarização do território e, no final de março de 2013, foi deflagrada a Operação Tapajós, com aproximadamente duzentos e cinquenta integrantes da FNSP ${ }^{8}$, Polícia Federal, Polícia Rodoviária Federal e Exército, com o objetivo declarado de garantir a segurança dos oitenta técnicos durante os levantamentos em campo.

É relevante observar que a relação entre os Munduruku e as forças de segurança estava estremecida desde a realização, no ano anterior, da Operação Eldorado, que resultou no assassinato de Adenilson Krixi Munduruku pelo delegado

8 A operação foi viabilizada graças à alteração das atribuições legais da FNSP, com a edição do Decreto Presidencial n . 7.957/2013, que criou a "Companhia de Operações Ambientais da Força Nacional de Segurança Pública" e autorizou o órgão a "prestar auxílio à realização de levantamentos e laudos técnicos sobre impactos ambientais negativos". Essa alteração legislativa e institucional atendeu a pedido feito pelo Ministério de Minas e Energia à Presidência da República, com o intuito de assegurar a continuidade do licenciamento da UHE São Luiz do Tapajós (Diniz 2013). 
da Polícia Federal responsável ${ }^{9}$. Sendo assim, a Operação Tapajós concretizou-se em um contexto no qual os Munduruku mantinham desconfiança quanto à atuação das forças policiais. Embora, oficialmente, o governo tenha afirmado que os militares não adentrariam o território indígena, os Munduruku denunciaram a realização de uma incursão militar na aldeia Sawré Muybu, durante a madrugada de 29 de março de 2013. Os indígenas observaram marcas de voadeiras e pegadas de botas nas proximidades do porto da aldeia; durante o dia, helicópteros sobrevoaram a área. Essas ocorrências foram interpretadas pelos Munduruku como tentativas de intimidação (Valle 2013).

Nesse clima, o governo federal, finalmente, adotou as primeiras providências para iniciar o diálogo com os indígenas, convocando reunião na Câmara dos Vereadores de Itaituba, em 15 de março de 2013, na qual apenas vinte indígenas se fizeram presentes (Brasil, Secretaria-Geral da Presidência da República 2015). Ficou acordado que seria realizado um novo encontro, desta vez no município de Jacareacanga.
Importante sublinhar que o agendamento de reuniões nos centros urbanos jamais foi endossado pelo povo Munduruku, que reivindicava reuniões nas aldeias, considerando não apenas os enormes desafios logísticos para o deslocamento de grande contingente para as cidades (o que resultaria na dificuldade de acesso às lideranças mais velhas, por exemplo), mas sobretudo o fato de que a consulta prévia deve ser "culturalmente apropriada".

No dia 25 de abril de 2013, representantes do governo federal dirigiram-se a Jacareacanga, onde apresentaram a "Proposta do Plano de Consulta para os Aproveitamentos Hidrelétricos de São Luiz do Tapajós e Jatobá” (Brasil, SecretariaGeral da Presidência da República 2013b). O plano daria início à etapa pré-consultiva, que visa a pactuação conjunta dos detalhes práticos do diálogo: calendário das reuniões, local e logística.

Além dos representantes do governo, estiveram presentes lideranças e vereadores Munduruku, bem como membros da prefeitura municipal. Os indígenas compareceram em pequeno número. Segundo o governo, a

9 A operação, fruto de decisão judicial da Justiça Federal em Mato Grosso, ocorreu em 6 de novembro de 2012, com o escopo de desativar garimpos ilegais no interior da TI Munduruku e destruir as balsas de garimpeiros nas proximidades da aldeia Teles Pires (Palmquist 2016). Após se desentender com lideranças às margens do rio, o delegado que estava à frente da operação matou Adenilson Krixi Munduruku com quatro tiros, sendo três nas pernas e um na nuca. A PF entendeu que o delegado agiu em legítima defesa e abriu inquérito para investigar a conduta dos índios (Palmquist 2016). O MPF, por sua vez, denunciou o delegado à Justiça Federal, mas o processo está pendente de julgamento pelo Tribunal do Júri (Brasil, Ministério Público Federal 2014b). O crime foi discutido em audiência pública na Comissão de Direitos Humanos da Câmara dos Deputados, em Brasília. Na ocasião, o representante do MPF reportou à comissão provas que demonstravam abusos cometidos pela PF: buracos de balas nas paredes das casas e da escola, cartuchos de projéteis de armas de fogo (o que descartava o argumento de que teriam sido usadas apenas balas de borracha) e frascos de spray de pimenta (Brasil, Câmara dos Deputados 2013). 
previsão era de que o encontro ocorresse em Jacareacanga, o que teria sido descumprido pelos indígenas, que aguardaram os representantes governamentais na aldeia Sai Cinza, a quarenta minutos de barco da sede municipal (Brasil, Secretaria-Geral da Presidência da República 2015). "Por conta do compromisso firmado anteriormente, e pela questão de segurança, os representantes governamentais decidiram não se deslocar até a aldeia e manter a realização do encontro na cidade", justificou o governo (Brasil, Secretaria-Geral da Presidência da República 2015). Assim, não houve definição e a proposta de plano de consulta do governo foi enviada aos indígenas através dos vereadores de Jacareacanga, Pará.

Os Munduruku reuniram-se na aldeia para aguardar o encontro e contradisseram a versão do governo: afirmam que não houve concordância quanto à realização da reunião na sede de Jacareacanga e que os representantes do governo não aceitaram se reunir na aldeia por temerem sofrer violência ${ }^{10}$. Os indígenas criticaram a militarização das reuniões, pois "não é possível ter diálogo com armas apontadas nas nossas cabeças":

E agora o governo chega novamente
armado com suas tropas para uma
reunião com o nosso povo, e inventa
todo tipo de mentira, manipulações
e distorções sobre nós Munduruku.
Nós queremos o diálogo, mas não
é possível ter diálogo com armas
apontadas nas nossas cabeças. E
achamos que talvez o governo não
queira dialogar, porque quem quer
dialogar não mata indígena, não
invade aldeias e nem vem armado com
policiais e helicópteros (Associação
Indígena Pusuru 2013).

Denunciaram pela primeira vez as tentativas de divisão (já que o plano previa consultar apenas quatro das 130 aldeias), cooptação e assédio de lideranças pelo governo federal ${ }^{11} \mathrm{e}$, finalmente, solicitaram tempo para participarem de "oficinas de

10 “Os representantes Tiago Garcia e Nilton Tubino, da Secretaria Geral da Presidência da República, afirmaram aos vereadores Munduruku de Jacareacanga que não viriam à aldeia porque temiam violência da nossa parte, que nós estávamos esperando por eles armados e com gaiolas para prendê-los. O governo está tentando se fazer de vítima, e isso não é verdade. Quem chegou armado na cidade de Jacareacanga foi o governo, com a Polícia Federal e a Força Nacional. Segundo Nilton, o ministro Gilberto Carvalho desautorizou a delegação a vir a nossa aldeia, e tentou impor uma reunião na cidade de Jacareacanga, sob presença militar. E isso nós não aceitamos. Essa reunião já tinha sido desmarcada uma vez. Ela deveria ter acontecido no dia 10 de abril, mas por causa da Operação Tapajós, nós ficamos com medo de um ataque igual ao que aconteceu na aldeia Teles Pires em novembro do ano passado, quando assassinaram nosso parente Adenilson” (Associação Indígena Pusuru 2013).

11 "Exigimos que o governo pare de tentar nos dividir e manipular, pressionando individualmente nossas lideranças, caciques ou vereadores. Lembramos que quem responde oficialmente pelo nosso povo são as coordenações das associações Munduruku, chamadas Pusuru e Pahyhy, as entidades representativas de todas as comunidades Munduruku. Somos um só povo, todas as nossas decisões são sempre coletivas e nós as expressamos sempre através das associações" (Associação Indígena Pusuru, 2013). 
capacitação" sobre a Convenção n $.169^{12}$ (Figura 1).

O início das reuniões não significou a interrupção do licenciamento ambiental. Ao final do mês de abril, cerca de cento e cinquenta indígenas fizeram passeata em Jacareacanga, em protesto contra a Operação Tapajós e a falta de diálogo. O cacique da aldeia Sawré Muybu criticou: “[o] governo quer impor seu projeto mesmo sem nos consultar” (Clark 2013b). E concluiu: “[n] ão queremos ameaça nem confronto, queremos que eles venham falar conosco e nos ouvir. $\mathrm{O}$ rio é nossa vida, e nossa vida não tem preço. $\mathrm{O}$ governo não pode nos comprar" (Clark 2013b). Os indígenas também exigiram que o governo parasse de tentar os "dividir e manipular, pressionando individualmente nossas lideranças [...]. Somos um povo só, todas as nossas decisões são sempre coletivas” (MAB Amazônia 2013).

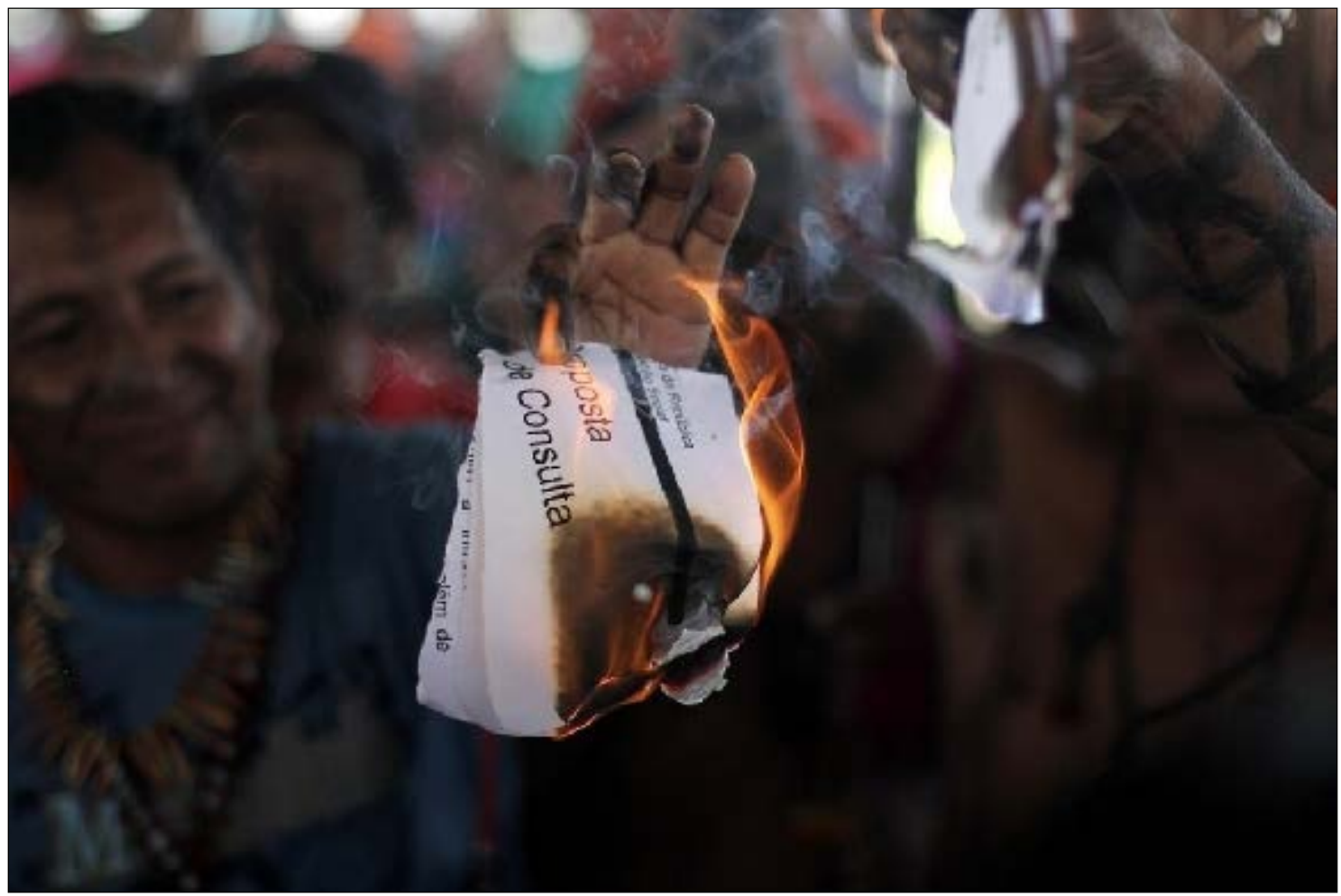

Figura 1 - Munduruku queimam proposta de plano de consulta apresentada pelo governo federal (Sposati 2013b).

12 “A reunião aconteceu na aldeia Sai Cinza nos dias 23, 24 e 25 de abril do corrente ano, nós o Povo Munduruku reunimos nesta referida aldeia para dialogar juntamente com o governo e o Ministério Público Federal para discutir a questão sobre a consulta prévia, mas, entendemos que nesses dias reunidos não é a realização da consulta prévia. Onde o Povo munduruku ainda não se encontra preparado para responder à altura a intenção do governo federal e também para discutir o nosso futuro em relação aos empreendimentos previstos para Região como um todo, entender mais sobre o que é a consulta prévia e dialogar com os nossos advogados que no caso é MPF onde queremos a participação efetiva do Ministério Público em todas as reuniões de esclarecimentos que futuramente irão acontecer em relação às comunidades indígenas Munduruku” (Associação Indígena Pusuru 2013). 
No início do mês de maio, os Munduruku viajaram até o rio Xingu para ocupar o canteiro de obras da UHE Belo Monte, com intento de pressionar o governo federal, impedindo a continuidade das obras daquele que, à época, era o principal projeto do governo. Os indígenas contaram com a parceria de lideranças dos beiradeiros de Montanha e Mangabal, comunidade tradicional do médio Tapajós, que também seria afetada diretamente pela formação do reservatório da hidrelétrica (Loures 2017). A consulta prévia assumiu papel de destaque na ação:

\begin{abstract}
Vocês sitiam nossos territórios com soldados e caminhões de guerra. Vocês fazem o peixe desaparecer. Vocês roubam os ossos dos antigos que estão enterrados na nossa terra. Vocês fazem isso porque têm medo de nos ouvir. De ouvir que não queremos barragem. De entender porque não queremos barragem (Carta da ocupação de Belo Monte $\left.\mathrm{n}^{\circ} 12013\right)$.
\end{abstract}

Durante a ocupação, ficou explícita a oposição dos Munduruku à estratégia do governo federal, que se tornou recorrente na relação com os povos indígenas afetados pela UHE Belo Monte: "negociação" de bens de consumos (principalmente carros e voadeiras), além das ações previstas nas condicionantes das licenças ambientais (postos de saúde, casas e escolas), com o intuito de silenciar e garantir a desocupação do canteiro de obras (E. Libardi, comunicação pessoal, 2015). Nesse cenário, os representantes do governo federal e da Norte Energia S.A. caracterizavam os indígenas como interesseiros e gananciosos. Os Munduruku, por sua vez, condicionaram a desocupação a uma definição concreta quanto à observância do direito à consulta e marcaram posição contrária à "lista de pedidos":

Não estamos aqui para negociar com o Consórcio Construtor Belo Monte. Não estamos aqui para negociar com a empresa concessionária Norte Energia. Não temos uma lista de pedidos ou reivindicações específicas para vocês. Nós estamos aqui para dialogar com o governo. Para protestar contra a construção de grandes projetos que impactam definitivamente nossas vidas. Para exigir que seja regulamentada a lei que vai garantir e realizar a consulta prévia - ou seja, antes de estudos e construções! Por fim, e mais importante, ocupamos o canteiro para exigir que seja realizada a consulta prévia sobre a construção de empreendimentos em nossas terras, rios e florestas. E para isso o governo precisa parar tudo o que está fazendo. Precisa suspender as obras e estudos das barragens. Precisa tirar as tropas e cancelar as operações policiais em nossas terras" (Carta da ocupação de Belo Monte $\mathrm{n}^{\circ} 2$ 2013).

O governo federal, então, publicou a nota "Esclarecimentos sobre a consulta aos Munduruku e a invasão de Belo Monte", 
na qual afirma que "pretensas lideranças Munduruku têm feito propostas contraditórias e se conduzido sem a honestidade necessária a qualquer negociação" (Brasil, Secretaria-Geral da Presidência da República 2013a). Acusava os indígenas de terem sequestrado e ameaçado de morte funcionários do governo, e sugeria que a oposição ao projeto manifestada por essas "pretensas lideranças" decorria de seu envolvimento "com o garimpo ilegal de ouro no Tapajós e afluentes" (Brasil, Secretaria-Geral da Presidência da República 2013a).

As acusações geraram revolta nos indígenas e um confronto de proporções mais graves tornou-se iminente ${ }^{13}$. A FNSP realizou cerco no canteiro de obras, impedindo a entrada de jornalistas, enfermeiros e apoiadores dos indígenas. Bloqueou o acesso de alimentos e de água, tornando praticamente inviável a permanência no local (Loures 2017). As condições do canteiro de obras eram insalubres, não havia sombra, água, comida, lugares para acomodação. Então, o ministro Gilberto Carvalho enviou uma carta aos Munduruku, propondo reunião em Brasília para a construção de um plano de consulta para os empreendimentos da bacia do Tapajós (Carvalho 2013):

A perspectiva que defendemos é de ampliar não só o direito de consulta, mas a participação dos indígenas nos debates sobre a região do Tapajós e sobre o modelo energético do Brasil. Nesse sentido, e dando continuidade às discussões iniciadas com lideranças Munduruku no dia 15 de março e no dia 25 de abril, propomos os seguintes compromissos:

1. Realização de uma reunião em Brasília, no prazo de 15 dias, entre lideranças indicadas pelo Povo Munduruku e o Ministro Chefe da Secretaria-Geral da Presidência da República, para diálogo e construção de um plano de consulta para a bacia do Tapajós, com participação do Ministério Público Federal;

2. Realização de reuniões com outros ministérios, em Brasília, para monitoramento da pauta apresentada durante a Assembleia Geral do Povo Munduruku, em janeiro de 2013;

3. Realização de nova reunião em Jacareacanga/PA, no prazo de 01 mês, coordenada pelo Secretário Nacional de Articulação Social, Paulo Maldos, para pactuação do procedimento de consulta adequado e construído entre governo federal e lideranças indígenas. Para isso, é necessária a desocupação do canteiro de obras de Belo Monte (Carvalho 2013).

Paralelamente, a Norte Energia, empresa concessionária de Belo Monte, obteve decisão judicial determinando a imediata desocupação

13 De acordo com o texto publicado pelos indígenas, "Os bandidos, os violadores, os manipuladores, os insinceros e desonestos são vocês. E ainda assim, nós permanecemos calmos e pacíficos. Vocês não. Vocês proibiram jornalistas e advogados de entrar no canteiro, e até deputados do seu próprio partido. Vocês mandaram a Força Nacional dizer que o governo não irá dialogar com a gente. Mandaram gente pedindo listas de pedidos. Vocês militarizaram a área da ocupação, revistam as pessoas que passam e vem, a nossa comida, tiram fotos, intimidam e dão ordens” (Carta da ocupação de Belo Monte nº 4 2013). 
do canteiro de obras e autorizando o uso de força policial $^{14}$. Os Munduruku deixam a área após sete dias de ocupação, sob o anúncio de que a luta não $\operatorname{arrefeceria}^{15}$. E não arrefeceu.

\section{Permaneceram alojados em Altamira} durante um mês, para aguardar definição do governo federal, o que não ocorreu, e tornaram a ocupar o canteiro, em $27 \mathrm{de}$ maio de 2013. Pautaram a realização da consulta prévia e a imediata "suspensão dos estudos e da construção das barragens que inundam os nossos territórios, que cortam a floresta no meio, que matam os peixes e espantam os animais, que abrem o rio e a terra para a mineração devoradora" (Carta da ocupação de Belo Monte $\left.n^{\circ} 72013\right)^{16}$. A Norte Energia apresentou à Justiça novo pedido de desocupação dos canteiros (Sposati 2013a). Os Munduruku, no entanto, avisaram que não desocupariam o canteiro e atribuíram ao governo federal a responsabilidade por eventual tragédia que viesse a acontecer: "[v] ocês querem nos ver amansados e quietos, obedecendo a sua civilização sem fazer

14 Consta no sítio eletrônico do MPF: "A Funai informou ao MPF que os índios estavam debatendo contrapropostas para encaminhar ao governo federal, mas foram surpreendidos com a ordem de despejo já na madrugada de hoje. $\mathrm{O}$ MPF vai pedir à Justiça Federal que suspenda a reintegração, porque considera que as negociações tinham sido iniciadas e a manifestação é pacífica. A decisão da desembargadora Selene Almeida se baseou em grande parte em um relatório feito pela Polícia Federal de Altamira, que é datado do último domingo (5) e não está atualizado com as informações mais recentes, como a evolução das negociações. O relatório policial contradiz as informações da Funai e mostra uma situação de risco na ocupação. Preocupa o MPF a possibilidade de a desembargadora ter decidido sem as informações atualizadas fornecidas pela Funai, que tinha sido designada pela própria Justiça Federal para acompanhar e relatar a situação nos canteiros. A presença de crianças no acampamento é outra razão para o máximo de cautela na operação" (Brasil, Ministério Público Federal 2013b).

15 "Nós fomos retirados ontem do canteiro por uma decisão judicial. Durante a ocupação, vocês barraram pessoas, censuraram jornalistas, impediram advogados, não deixaram entrar carvão para cozinhar nossa comida. Carros com agentes de saúde foram bloqueados, tiveram que entrar a pé. Vocês não nos deixaram montar nosso rádio para falarmos com nossos parentes, e nossas famílias ficaram preocupadas. Vocês nos sitiaram com a Polícia Militar, Rotam, Tropa de Choque, Força Nacional, Polícia Federal, Polícia Civil, Exército e Polícia Rodoviária Federal o tempo todo. Gerentes e chefes da Norte Energia e Consórcio Construtor Belo Monte nos assediavam, intimidavam e pressionavam. Vocês tentaram nos sufocaram com mentiras na imprensa, com telefonemas pressionando e intimidando parceiros e jornalistas. Como sempre, vocês pressionaram e manipularam parentes nossos, tentando nos colocar um contra os outros" (Carta da ocupação de Belo Monte nº 6 2013).

16 "O seu governo disse que se nós saíssemos do canteiro, nós seríamos ouvidos. Nós saímos pacificamente - e evitamos que vocês passassem muita vergonha nos tirando à força daqui. Mesmo assim, nós não fomos atendidos. O governo não nos recebeu. Nós chamamos pelo ministro Gilberto Carvalho e ele não veio. Esperar e chamar não servem para nada. Então nós ocupamos mais uma vez o seu canteiro de obras. Não queríamos estar de volta no seu deserto de buracos e concreto. Não temos nenhum prazer em sair das nossas casas nas nossas terras e pendurar redes nos seus prédios. Mas, como não vir? Se não viermos, nós vamos perder nossa terra. Nós queremos a suspensão dos estudos e da construção das barragens que inundam os nossos territórios, que cortam a floresta no meio, que matam os peixes e espantam os animais, que abrem o rio e a terra para a mineração devoradora. Que trazem mais empresas, mais madeireiros, mais conflitos, mais prostituição, mais drogas, mais doenças, mais violência. Nós exigimos sermos consultados previamente sobre essas construções, porque é um direito nosso garantido pela Constituição e por tratados internacionais" (Carta da ocupação de Belo Monte $n^{\circ} 7$ 2013). 
barulho. Mas nesse caso, nós sabemos que vocês preferem nos ver mortos porque nós estamos fazendo barulho" (Carta da ocupação de Belo Monte $\mathrm{n}^{\circ} 8$ 2013). Esclareceram que não aceitariam a realização da consulta enquanto o licenciamento ambiental estivesse em andamento ${ }^{17}$.

No dia 4 de junho de 2013, após nove dias de ocupação, o governo federal enviou a Altamira um avião para levar os indígenas a Brasília, com o intuito de discutir acordos sobre o processo de consulta. Os indígenas compreenderam que o momento não era oportuno para estabelecer acordos sem conversar com todos os caciques e lideranças (a maior parte dos que estavam na ocupação são jovens lideranças); tratava-se apenas de reafirmar a obrigação de o governo federal respeitar o direito à consulta (Sposati 2013c). Enfatizaram também que não apresentariam lista de reinvindicações, "porque não se negocia nem território, nem vida" (Carta da ocupação de Belo Monte no 9 2013) ${ }^{18}$.

O ministro Gilberto Carvalho recusouse a receber todos os Munduruku e exigiu a composição de uma comissão de representantes, algo recorrente nas convocatórias de reuniões de iniciativa do governo. Os Munduruku pontuaram que só aceitariam se reunir com o ministro caso todos fossem recebidos, inclusive as crianças (Palmquist 2016). Após insistência, os indígenas conseguiram ser recebidos pelo ministro. $\mathrm{O}$ encontro tornou evidente alguns dos impasses entre as partes

17 "Agora quem pediu para nos matar foi a Norte Energia, que é do governo e de empresários. Ela pediu para o juiz federal, que autorizou a polícia a nos bater e matar se for preciso. A culpa é de todos vocês se algum de nós morrer. Chega de violência. Parem de nos ameaçar. Nós queremos a nossa paz e vocês querem a sua guerra. Parem de mentir para a imprensa que estamos sequestrando trabalhadores e ônibus e causando transtornos. Está tudo tranquilo na ocupação, menos da parte da polícia mandada pela Justiça mandada pela Norte Energia mandada pelo governo. Vocês é que nos humilham e ameaçam e intimidam e gritam e assassinam quando não sabem o que fazer. Nós exigimos a suspensão da reintegração de posse. Até dia 30 de maio de 2013, quinta-feira de manhã, o governo precisa vir aqui e nos ouvir. Vocês já sabem da nossa pauta. Nós exigimos a suspensão das obras e dos estudos de barragens em cima das nossas terras. E tirem a Força Nacional delas. As terras são nossas. Já perdemos terra o bastante.Vocês querem nos ver amansados e quietos, obedecendo a sua civilização sem fazer barulho. Mas nesse caso, nós sabemos que vocês preferem nos ver mortos porque nós estamos fazendo barulho" (Carta da ocupação de Belo Monte $\left.\mathrm{n}^{\circ} 82013\right)$

18 "Viemos aqui falar para vocês da outra tragédia que iremos lutar para evitar: a perda do nosso território e da nossa vida. Nós não viemos negociar com vocês, porque não se negocia nem território nem vida. Nós somos contra a construção de barragens que matam a terra indígena, porque elas matam a cultura quando matam o peixe e afogam a terra. E isso mata a gente sem precisar de arma. Vocês continuam matando muito. Vocês simplesmente matam muito. Vocês já mataram demais, faz 513 anos. Mas não. Vocês atropelam tudo e fazem o que querem. E para isso, vocês fazem de tudo para dividir os povos indígenas. Nós viemos aqui dizer para vocês pararem, porque nós vamos resistir juntos e unidos. Estamos reunidos há 35 dias em Altamira, e por 17 dias nós ocupamos a principal hidrelétrica que vocês estão construindo" (Carta da ocupação de Belo Monte no 9 2013). 
quanto à finalidade do direito à consulta prévia:

Valdenir Munduruku: "nós queremos que nessa consulta, que ao final dela a gente possa dar nossa posição, se a gente quer ou não, porque não adianta a gente ser consultado, se ao final a gente dizer que não quer esse projeto, e mesmo assim ela venha a ser construída".

Gilberto Carvalho: "vou ter que ser muito sincero com vocês, eu espero que não seja isso, porque eu acho que depois que for tudo bem explicado não será essa resposta, mas se for perguntado e for dito não, aí o governo vai ter que dar uma pensada, mas a lei dá o direito ao governo de realizar, mesmo que a consulta prévia diga não, isso tá na Convenção da OIT, isso está na lei” (Instituto Socioambiental 2013).

O ministro Gilberto Carvalho concedeu entrevista ao Jornal Nacional logo após a reunião: "ouvimos longamente a fala [dos Munduruku], as críticas, mas fomos absolutamente claros com eles, dizendo que o governo não vai abrir mão de seus projetos" (Carta da ocupação de Belo Monte n ${ }^{\circ} 10$ 2013). O discurso do ministro explicita a postura do governo que permeou todo o processo, no sentido de que a consulta seria uma etapa meramente informativa, sem que os indígenas tivessem poder de decidir ou até mesmo de produzir alterações substanciais no projeto, compreensão absolutamente contrária à Convenção ${ }^{\circ} .169$.

Os Munduruku interpretaram o discurso como indicativo da ineficácia do processo de consulta a que o governo buscava dar início: "Entendemos que o governo está dizendo: 'nós vamos construir as hidrelétricas nas terras de vocês, não importa o que vocês digam. E mesmo que vocês sejam consultados, nós não vamos considerar a opinião de vocês'” (Carta da ocupação de Belo Monte n ${ }^{\circ}$ 10 2013). Os Munduruku ocuparam ainda a sede da Funai em Brasília, para pressionar o governo em busca de um compromisso mais concreto, asseverando que a consulta seria respeitada, mas não tiveram sucesso.

Em meio à ocupação de Belo Monte, houve uma aproximação com os povos indígenas que são afetados pela UHE Belo Monte, notadamente aos Juruna (Yudjá) e Xipaya, o que proporcionou aos Munduruku uma visão bastante crítica acerca das práticas de "negociação" conduzidas pelo governo federal e pela Norte Energia, em especial, de sua principal faceta: a política de compensações.

Em 21 de junho de 2013, os Munduruku retiveram três biólogos que estavam coletando materiais no entorno da Terra Indígena Munduruku, próximo a um local sagrado para os indígenas. Os biólogos foram conduzidos até Jacareacanga e, para liberá-los, os indígenas exigiram a interrupção dos estudos. O governo, enfim, se comprometeu a suspendê-los e a dar prosseguimento à consulta, em troca da liberação dos técnicos (Clark 2013a). 
A expectativa dos indígenas era de que o governo tentasse alavancar um processo adequado, mas eles foram surpreendidos com nova ofensiva e com a entrada em cena de novos agentes políticos. A prefeitura de Jacareacanga orquestrou um golpe na Associação Pusuru, principal associação civil dos Munduruku, que até então encampava a resistência. Em 3 de agosto de 2013, representantes de mais de cento e dez aldeias, entre os quais oitenta e três caciques, reuniram-se na cidade de Jacareacanga, em assembleia extraordinária (Santana 2013a). "A pauta dizia que era para avaliar os últimos acontecimentos do movimento. Era para fortalecer a luta contra os grandes projetos e a organização dos Munduruku de uma forma geral", observou Jairo Saw Munduruku (Santana 2013a). No entanto, para surpresa dos próprios indígenas, o encontro foi conduzido pelo prefeito, Raulien Queiroz, o que foge absolutamente da dinâmica tradicional dos Munduruku, que se encarregam eles próprios de conduzir os encontros de que participam. Raulien discursou sobre a necessidade de união entre indígenas e não indígenas, afirmando que todos deveriam convergir em torno do desenvolvimento do município e do bem-estar coletivo (Monteiro 2013).

Sob a guarda de grande efetivo de policiais militares, integrantes da prefeitura conseguiram alterar a pauta da reunião, para discutir supostos atos de "vandalismo" e "depredação" cometidos por indígenas assim foram qualificadas, pela prefeitura, as ações diretas contrárias à UHE. A prefeitura impôs a eleição de uma nova diretoria para a Pusuru, ameaçando não garantir a alimentação para o encontro e não fornecer combustível para o retorno às aldeias, como havia sido previamente acordado: "[q]uem não se adequar às condições, que assuma as despesas do evento" (Palmquist 2016). As práticas surtiram o efeito desejado e a diretoria da Pusuru foi substituída por indígenas dispostos a colaborar com o governo federal (Palmquist 2016). A ação desestruturou momentaneamente a resistência dos Munduruku e marcou o deslocamento do protagonismo na luta contra a hidrelétrica das associações civis para o Movimento Iperěg Ayũ.

Dez dias depois da assembleia, o governo federal descumpriu o acordo e, sem ao menos tentar avançar no diálogo, comunicou à Funai a decisão de retomar o licenciamento ambiental (Santana 2013b). A constante tentativa do governo de postergar ao máximo a consulta contraria os parâmetros jurídicos que exigem que o diálogo tenha início desde as primeiras etapas de planejamento do projeto. 
Apenas no início de 2014, o governo federal convocou reunião com os Munduruku para discutir a pactuação do plano de consulta na aldeia Praia do Mangue, em Itaituba. Mais uma vez, o fato de o governo ter agendado a reunião para aldeia localizada no centro urbano de Itaituba fez com que os indígenas comparecessem em pequeno número. Na ocasião, indígenas e Ministério Público Federal identificaram a necessidade de se realizar oficinas de capacitação sobre a Convenção n ${ }^{\circ} .169$ junto aos Munduruku (Brasil, Ministério Público Federal 2014c).

Enquanto as oficinas ainda estavam sendo planejadas e organizadas, o governo federal convocou nova reunião para os dias 2 e 3 de setembro de 2014, na aldeia Praia do Mangue (Brasil, Ministério Público Federal 2014c), em meio à campanha eleitoral para a Presidência da República (Palmquist 2016). Os indígenas não foram informados com a antecedência devida e, até as vésperas, pairavam dúvidas sobre se o encontro de fato aconteceria. A confirmação da reunião veio apenas no dia 31 de agosto (L. C. L. Boaventura, comunicação pessoal, Santarém, 2016). Os representantes do governo estavam determinados a sair do encontro com o plano de consulta pactuado (L. C. L. Boaventura, comunicação pessoal, Santarém, 2016) e tentaram ajustar o cronograma da consulta à agenda do setor energético brasileiro - que desejava levar o empreendimento a leilão ainda no final de 2014 - e ao calendário das eleições presidenciais. Os prazos que o governo queria impor eram exíguos. A previsão era de que a consulta fosse iniciada e concluída em apenas quarenta e cinco dias (de 2 de setembro a 18 de outubro).

A justificativa para isso era a necessidade de expansão da oferta energética nacional. Ademir Kaba Munduruku ironizou: o governo queria conduzir uma "consulta às pressas", não uma "consulta prévia" (L. C. L. Boaventura, comunicação pessoal, Santarém, 2016). Os Munduruku não aceitaram o cronograma, pois queriam tempo para participar das oficinas de capacitação, que já estavam sendo planejadas pelo MPF e por organizações indigenistas e ambientalistas (Brasil, Ministério Público Federal 2014a). Acordou-se, então, que só depois das oficinas sobre Convenção $\mathrm{n}^{\circ} .169$ é que seriam retomadas as tratativas para a pactuação do plano de consulta (Brasil, Ministério Público Federal 2014a).

Passado pouco mais de uma semana após o encontro, em 11 de setembro de 2014, o governo federal publica a Portaria nº.485/2014, através do Ministério de Minas e Energia, agendando o leilão da UHE São Luiz do Tapajós para o dia 15 de dezembro (Brasil, Ministério de Minas e Energia 2014). Os Munduruku interpretaram o ato como 
uma demonstração de má-fé do governo ${ }^{19}$, que quebrava o acordo estabelecido.

Reagindo à pressão dos indígenas, o governo anunciou a revogação da portaria, com base na "necessidade de adequações aos estudos associados ao tema do componente indígena” (Brasil, Ministério de Minas e Energia 2014). A vacilação reforçou a desconfiança por parte dos indígenas:

\begin{abstract}
Nós, povo Munduruku, aprendemos com nossos ancestrais que devemos ser fortes como a grande onça pintada e nossa palavra deve ser como o rio, que corre sempre na mesma direção. O que nós falamos vale mais que qualquer papel assinado. Assim vivemos há muito séculos nesta terra. $\mathrm{O}$ governo age como a sucuri gigante, que vai apertando devagar, querendo que a gente não tenha mais força e morra sem ar. Vai prometendo, vai mentindo, vai enganando (Comunicado ao Governo Federal 2014).
\end{abstract}

Ao final de setembro, a equipe responsável pelo
Estudo do Componente Indígena entregou-o para a avaliação do corpo técnico do Ibama e da Funai, e os Munduruku souberam, através da imprensa, que o empreendimento removeria as três aldeias da Terra Indígena Sawré Muybu (Milanez 2014). O item "percepção dos grupos indígenas quanto ao empreendimento" relatava o "histórico de tratativas entre o Governo e os Munduruku" em relação ao empreendimento (ECI 2014:209).

No Estudo, era possível antever que a nova estratégia do governo federal seria sustentar que os indígenas estariam boicotando a consulta: os fatos são editados de maneira a fazer crer que o governo federal envidou todos os esforços para viabilizar a consulta, que só não teria ocorrido por responsabilidade dos indígenas ${ }^{20}$. As reuniões convocadas seriam provas de que o governo estava aberto ao diálogo. O governo federal, através do

19 "Nós Munduruku estamos indignados com o governo. Nos dias 2 e 3 de setembro, guerreiros e guerreiras Munduruku e outras populações ameaçadas pelo projeto de construção de usinas no rio Tapajós, tiveram uma reunião com o governo federal, representado por pessoas da Advocacia Geral da União, Ministério do Planejamento, Secretaria Geral da Presidência da República, Funai, Ministério da Justiça e Ministério de Minas e Energia. A reunião foi convocada pelo governo para discutir a Consulta Prévia, Livre, Informada e Consentida prevista na Convenção 169 da OIT, depois que a Justiça Federal obrigou o governo a cumprir a Convenção. Os Munduruku explicaram ao governo que estavam preparando uma formação sobre a Convenção 169, porque o assunto é muito complexo, e que só depois disso vão decidir quando e como será feita a consulta. Este é o direito que temos, garantido pela Convenção 169, e o governo se comprometeu de fazer o diálogo com nós de acordo com OIT e respeitar a nossa decisão no processo de diálogo. Na sexta feira, dia 12 de setembro, ficamos sabendo que o governo publicou no Diário Oficial da União que fará o leilão da usina de São Luiz do Tapajós no dia 15 de dezembro deste ano. Ficamos muito bravos com o fato de a presidente Dilma, o Gilberto Carvalho, o Paulo Maldos, o Nilton Tubino, o Tiago Garcia, representantes de ministérios e outras autoridades dizer que iam respeitar o direito do povo Muduruku, e depois parece que este compromisso não vale nada. Agindo assim o governo não está cumprindo suas palavras, não está agindo com boa fé e não está respeitando a Organização Internacional do Trabalho" (Carta do povo Munduruku ao governo federal 2014).

20 Segundo o ECI, “Apesar dos esforços, não foi possível constituir o diálogo necessário para o estabelecimento do Plano de Consulta em conversa e acordo com os Munduruku. A dificuldade manifestada por eles em compreender o processo de licenciamento frente o direito à oitiva resultou na impossibilidade de se realizar uma nova reunião" (ECI 2014:212-213). 
órgão encarregado de sua representação jurídica, passou a argumentar na justiça que os Munduruku não queriam ser consultados (Brasil, Ministério Público Federal 2012a). O argumento não foi aceito e, em 30 de abril de 2015, o juiz sentenciou favoravelmente aos Munduruku, reconhecendo a obrigação de o governo consultá-los (Brasil, Justiça Federal 2015).

A demarcação da Terra Indígena Sawré Muybureivindicação que, assim como o direito à consulta, assumiu papel central na luta contra a construção da hidrelétrica - estava paralisada. Os indígenas acreditavam que havia um desígnio, por parte do setor elétrico do governo, de que o território não poderia ser demarcado. A desconfiança se confirmou em reunião com a então presidenta da Funai, Maria Augusta Assirati, em setembro de 2014. A presença de funcionários do setor elétrico no encontro já dava o tom da interferência a que o órgão indigenista estava sendo submetido (Naka 2015:22). Aos indígenas, Assirati admitiu que a paralisação da demarcação se devia à hidrelétrica (Autodemarcação no Tapajós 2014). Após o episódio, Assirati pediu exoneração: "Nós tivemos que descumprir esse compromisso [demarcação] em razão da prioridade que o governo deu ao empreendimento. Isso é grave”. Criticou, ainda, a visão de parte do governo de que a consulta aos indígenas seria um empecilho burocrático (Aranha 2015).
Ainda ao final do mês de setembro, tiveram início as discussões sobre a Convenção $\mathrm{n}^{\circ} 169$. Os Munduruku tentavam evitar um processo de consulta enviesado e que não respeitasse o que lhes era garantido pelo direito, daí a decisão de debater a Convenção $\mathrm{n}^{\circ} .169$ e o direito à consulta antes de uma nova reunião com o governo. Solicitaram apoio ao MPF, a organizações e movimentos sociais parceiros. Recebi convite do MPF para contribuir com a construção das oficinas. Nos meses anteriores, dedicamo-nos ao planejamento logístico dos encontros e à elaboração do material didático, posteriormente traduzido para a língua Munduruku. As primeiras oficinas foram ministradas na aldeia Waro Apompu, localizada às margens do rio Cururu, no alto Tapajós, nos dias 24 e 25 de setembro, e na Praia do Mangue, em Itaituba, nos dias 29 e 30. Os dois encontros contaram com a participação de ao menos quatrocentos indígenas.

Os Munduruku decidiram construir um protocolo de consulta, documento no qual expõem à sociedade e ao Estado como estão organizados social e politicamente, como se fazem representar e como tomam suas decisões; em suma, reivindicam como deve ser uma consulta culturalmente adequada. Para tanto, elaboraram um texto base, discutido entre os indígenas nos meses seguintes, e, durante assembleia geral extraordinária realizada 
na aldeia Sai Cinza, nos dias 13 e 14 de dezembro do mesmo ano, aprovaram o Protocolo de Consulta Munduruku (Munduruku 2014). Mais de oitocentos indígenas participaram deste último encontro.

Nesse ínterim, os indígenas iniciaram a autodemarcação da Terra Indígena Sawré Muybu, seguindo as coordenadas geográficas delimitadas pelo Relatório Circunstanciado de Identificação e Delimitação, que à época ainda não havia sido publicado pela Funai, visando, dentre outras questões, pressionar o governo para demarcar o território. Em meados de outubro, guerreiros munduruku de toda a bacia viajaram pelo rio Tapajós em direção ao Daje Kapap Eypi, para fazer autodemarcação (Molina 2017). A ação estreitou a aliança dos indígenas com a comunidade tradicional de beiradeiros de Montanha e Mangabal, que participaram ativamente da autodemarcação.

Entre novembro de 2014 e abril de 2016, o governo federal não tomou qualquer iniciativa para pactuar o processo de consulta com os Munduruku, ao passo que representantes do alto escalão do setor elétrico do governo federal atribuíam a morosidade na construção da hidrelétrica ao Ibama e à Funai, pressionando-os perante a imprensa (Borges 2015; Canal Energia 2015; Yahoo 2015;GVCES 2015).

Por outro lado, com a conclusão do Protocolo de Consulta Munduruku, os indígenas voltaramse a outras reivindicações e estratégias não diretamente relacionadas à consulta prévia (e que por isso não serão aprofundadas neste artigo), mas especialmente à demarcação da Terra Indígena Sawré Muybu, pleito que começou a ser atendido em 19 de abril de 2016, quando a Funai finalmente publicou o Relatório Circunstanciado de Identificação e Delimitação da Terra Indígena Sawré Muybu, dando início ao reconhecimento formal do território (Brasil, Fundação Nacional do Índio 2016).

Sem que a consulta prévia tivesse sido efetivamente iniciada, o Ibama arquivou o licenciamento ambiental da UHE São Luiz do Tapajós em 2 de agosto de 2016. As razões indicadas foram que o empreendedor, nos estudos de impacto ambiental, não conseguiu demonstrar a viabilidade do projeto. O Ibama também fez remissão aos pareceres técnico e jurídico da Funai, que apontaram a inconstitucionalidade da hidrelétrica, por implicar a remoção compulsória de três aldeias (o que é vedado pelo artigo $231, \S 5^{\circ}$ da Constituição Federal), bem como em razão da ausência de regulamentação da norma constitucional que prevê a possibilidade de exploração hidrelétrica em terras indígenas (artigos $231, \S 3^{\circ}$ e $176, \S 1^{\circ}$ ).

Mesmo com a publicação do Relatório e o arquivamento da UHE São Luiz do Tapajós, o governo federal segue sem concluir o processo administrativo de demarcação da Terra Indígena 
Sawré Muybu, o que fomenta diversos acintes aos direitos territoriais dos indígenas, tais como invasões, grilagem e extração ilegal de madeira. Os Munduruku também seguem lutando contra a violação do direito à consulta prévia quanto a outros empreendimentos que vêm sendo instalados na região, tais como os portos graneleiros em construção no distrito de Miritituba, em Itaituba, Pará.

\section{CONCLUSÃO}

Este artigo apresentou uma etnografia documental do conflito travado entre o povo indígena Munduruku e o governo federal em torno do projeto da Usina Hidrelétrica de São Luiz do Tapajós, na qual sublinho a reivindicação do direito à consulta prévia, livre e informada. Para produzir os dados, sistematizados durante pesquisa de mestrado e posteriormente atualizados, debruceime sobre documentos de diversas naturezas, com ênfase nas cartas publicadas pelos indígenas.

O governo federal (a anta) tentava construir uma mega-hidrelétrica no rio Tapajós - uma das maiores obras à época, em nível mundial -, com um orçamento bilionário. Lançou mão de diversos artifícios econômicos, jurídicos, políticos, militares e comunicacionais para minar a luta e as reivindicações dos indígenas e para avançar com a obra, à revelia da legislação. Destacamos a intervenção na organização política dos indígenas com o golpe na Associação Pusuru, a deslegitimação dos Munduruku perante a opinião pública através de notas que atribuíam a oposição à hidrelétrica aos interesses de exploração garimpeira, a não demarcação deliberada da Terra Indígena Sawré Muybu e o uso de instrumentos judiciais para suspender a ordem jurídica e permitir o avanço do projeto sem a realização de consulta prévia.

Tais "práticas de guerra" ${ }^{21}$ expressam as assimetrias que permearam o conflito e dão sentido à alusão, feita pelos próprios indígenas, à luta do jabuti contra a anta.

Superado o momento em que o governo federal simplesmente negava sua obrigação de realização de consulta à população indígena, o artigo demonstrou que o embate entre o governo e os Munduruku deu-se quanto à aplicação situacional da consulta prévia e explicitou que estes agentes conferem sentidos diferentes e, por vezes, antagônicos ao direito em disputa. A etnografia evidenciou que não se trata de um simples conflito interpretativo entre compreensões igualmente válidas: as práticas do

21 Acselrad (2014) destaca a presença de elementos comuns entre o "modo de operação de grandes interesses econômicos" e as "práticas de origem militar correntes no período de exceção", como a espionagem, técnicas de controle territorial, estratégias para dividir resistentes e para deslegitimar movimentos opositores perante a população local, entre outras artimanhas. 
governo violaram a legislação e, ao cabo, buscavam suprimir a possibilidade de participação efetiva dos indígenas no processo decisório quanto à construção ou não da hidrelétrica.

O governo federal enxergava a consulta prévia como obstáculo burocrático à construção da hidrelétrica, como a então presidenta da Funai admitiu (Aranha 2015). Em muitos momentos, o governo adotou posturas que não apenas contrariavam os indígenas, mas que violavam a própria legislação que rege a matéria, por exemplo, ao declarar que a decisão pela construção da hidrelétrica era irreversível, ao postergar ao máximo o início da consulta, ao militarizar os encontros, ao querer impor um calendário exíguo para as reuniões e ao desconsiderar a organização social e política dos indígenas, bem como sua forma de representação (Oliveira 2016).

Os Munduruku, tal como o jabuti, moveram-se de forma estratégica: fortaleceram sua organização social e política a partir de longas discussões em assembleias gerais e debates locais nas aldeias; teceram alianças com os beiradeiros de Montanha e Mangabal, com organizações não governamentais e com o Ministério Público Federal; denunciaram às instâncias internacionais os abusos cometidos pelo governo federal e publicaram cartas para se comunicar diretamente com a sociedade civil.
Os Munduruku identificaram as próprias "leis do governo" como possíveis vulnerabilidades da anta. Com frequência, denunciaram que o governo “não cumpre suas próprias leis”, "as leis que ele próprio criou".

Neste sentido, os Munduruku se apropriaram da consulta prévia e buscaram dar vida a este dispositivo legal, concebendo-o como um espaço "culturalmente adequado" que deveria lhes garantir a possibilidade de decidir sobre o futuro de suas vidas e de seus territórios, como manda a legislação. A oposição dos Munduruku jamais foi ao fato de serem consultados como argumentou o governo perante a justiça -, mas à forma enviesada como o governo conduzia o processo, o que fica claro no Protocolo de Consulta Munduruku.

A propósito, este artigo oferece elementos que permitem identificar que o Protocolo de Consulta Munduruku, quanto ao sentido que os Munduruku atribuem à consulta prévia ${ }^{22}$, é uma consolidação de diversas perspectivas que os indígenas já vinham expressando por meio de cartas desde o princípio da resistência à implantação de hidrelétricas na bacia do rio Tapajós.

Com o arquivamento da hidrelétrica, os Munduruku ensinam que o direito à consulta prévia pode ser um movimento estratégico e que os jabutis são capazes de derrotar uma enorme anta.

22 Ao dizer "sentidos" da consulta prévia, estou me referindo àquilo que Geertz (1998) chamou de sensibilidade jurídica enquanto diferentes sentidos de justiça próprios de cada povo. Esta reflexão será objeto de ulterior publicação. 


\section{REFERÊNCIAS}

Acselrad, H. 2014. Confluências autoritárias. Le Monde Diplomatique Brasil, 5 maio 2014. Disponível em: http://www.diplomatique.org.br/artigo.php?id=1655. Acesso em: 1 jun. 2020.

Aires de Casal, M. 1976 [1817]. Corografia brasílica ou relação historico-geografica do Reino do Brazil composta e dedicada a Sua Majestade fidelíssima por humpresbitero secular do Gram Priorado do Crato. Rio de Janeiro: Impressão Régia, Tomo 1.

Alencastro, C., e A. Souza. 2013. Gilberto Carvalho tem diálogo tenso com índios contrários à usina de Teles Pires. O Globo, 21 fev. 2013. Disponível em: http://oglobo.globo.com/economia/gilbertocarvalho-tem-dialogo-tenso-com-indios-contrarios-usina-de-teles-pires-7642233\#ixzz3EAU4i82q. Acesso em: 26 dez. 2019.

Aranha, A. 2015. “A Funai está sendo desvalorizada e sua autonomia totalmente desconsiderada”, diz ex-presidente. Entrevista com Maria Augusta Assirati. Apública, 27 jan. 2015. Disponível em: http:// apublica.org/2015/01/a-funai-esta-sendo-desvalorizada-e-sua-autonomia-totalmente-desconsideradadiz-ex-presidente/. Acesso em: 26 dez. 2019.

Arnaud, E. 1974. Os índios Munduruku e o Serviço de Proteção aos Índios. Boletim do Museu Paraense Emílio Goeldi. Nova Série, Antropologi(54):1-60.

Associação Indígena Pusuru (AIP). 2013. Carta do Povo Munduruku. Jacareacanga, 25 abr. 2013. Disponível em: http:/www.socioambiental.org/sites/blog.socioambiental.org/files/nsa/arquivos/ carta_munduruku_0.pdf. Acesso em: 26 dez. 2019.

Autodemarcação no Tapajós. 2014. Funai admite pressão e condiciona demarcação à hidrelétrica. Brasília: 17 set. 2014. Disponível em: https://autodemarcacaonotapajos.wordpress.com/2014/11/18/ video-funai-admite-pressao-e-condiciona-demarcacao-a-hidreletrica/?preview=true\&preview_id=108. Acesso em: 26 dez. 2019. 
Borges, A. 2015. São Luiz do Tapajós deve ser licitada até o fim deste ano. Estadão, 15 fev. 2015. Disponível em:http://economia.estadao.com.br/noticias/geral,sao-luiz-de-tapajos-deve-ser-licitadaate-o-fim-deste-ano-imp-,1634756. Acesso em: 26 dez. 2019.

Brasil. Câmara dos Deputados. 2013. Debate sobre a ação da Polícia Federal na área indígena Munduruku. Brasília: Câmara dos Deputados, 17 mar. 2013. Disponível em: http://www.camara.leg.br/internet/ sitaqweb/TextoHTML.asp?etapa=11\&nuSessao=0355/1. Acesso em: 26 dez. 2019.

Brasil. Conselho Nacional de Pesquisa Energética. 2011. Resolução no. 3. Brasília: CNPE, 3 maio 2011.

Brasil. Eletrobras. 2012. Ofício. CTA-DG-9397/2012. Rio de Janeiro: Eletrobras, 20 dez. 2012.

Brasil. Fundação Nacional do Índio. 2016. Funai aprova estudos das Terras Indígenas SawréMuybu (PA), Ypoi/Triunfo (MS), Sambaqui (PR) e Jurubaxi-Téa (AM). Funai, 19 abr. 2016. Disponível em: http://www.funai.gov.br/index.php/comunicacao/noticias/3712-funai-publica-estudos-dasterras-indigenas-sawre-muybu-pa-ypoi-triunfo-ms-sambaqui-pr-e-jurubaxi-tea-am. Acesso em: 26 dez. 2019.

Brasil. Justiça Federal. 2012. Decisão liminar na Ação civil pública nº 3883-98.2012.4.01.3902. Santarém, 25 set. 2012.

Brasil. Justiça Federal. 2015. Sentença na Ação Civil Pública nº. 3883-98.2012.4.01.3902. Itaituba: JFPA, 30 abr. 2015.

Brasil. Ministério de Minas e Energia. 2014. MME revoga portaria que definia diretrizes do leilão da UHE São Luiz do Tapajós. Brasília: MME, 16 set. 2014. Disponível em: http://www.mme.gov.br/web/guest/ pagina-inicial/outras-noticas/-/asset_publisher/32hLrOzMKwWb/content/mme-revoga-portaria-quedefinia-diretrizes-do-leilao-da-uhe-sao-luiz-do-tapajos;jsessionid=06974D1610BF8E36D0C6FF129995 C3BB.srv154. Acesso em: 26 dez. 2019. 
Brasil. Ministério Público Federal. 2012a. Ação Civil Pública nº. 3883-98.2012.4.01.3902. Santarém: MPF.

Brasil. Ministério Público Federal. 2012b. Ação Civil Pública no . 3947-44.2012.4.01.3600. Cuiabá: MPF, 8 mar. 2012b.

Brasil. Ministério Público Federal. 2013a. Ação Civil Pública no . 14123-48.2013.4.01.3600. Cuiabá: MPF, 26 set. 2013.

Brasil. Ministério Público Federal. 2013b. MPF quer continuidade das negociações com índios em Belo Monte. Belém: MPF, 9 maio 2013. Disponível em: http://www.prpa.mpf.mp.br/news/2013/mpf-pedecontinuidade-das-negociacoes-em-belo-monte. Acesso em: 5 abr. 2016.

Brasil. Ministério Público Federal. 2014a. Índios Munduruku vão definir formato e prazos de consulta sobre usina. Belém: Procuradoria da República no Pará, 8 set. 2014. Disponível em: http://www.prpa. mpf.mp.br/news/2014/indios-munduruku-vao-definir-formato-e-prazos-de-consulta-sobre-usina/. Acesso em: 24 mar. 2016.

Brasil. Ministério Público Federal. 2014b. MPF denuncia delegado da PF pelo assassinato de Adenilson Munduruku. Belém: MPF, 10 jul. 2014. Disponível em: http://www.prpa.mpf.mp.br/news/2014/mpfdenuncia-delegado-da-pf-pelo-assassinato-de-adenilson-munduruku. Acesso em: 24 mar. 2016.

Brasil. Ministério Público Federal. 2014c. Índios Munduruku vão definir formato e prazos de consulta sobre usina. Belém: MPF, 8 set. 2014. Disponível em: http://www.prpa.mpf.mp.br/news/2014/indiosmunduruku-vao-definir-formato-eprazos-de-consulta-sobre-usina/. Acesso em: 24 mar. 2016.

Brasil. Tribunal Regional Federal da $1^{\text {a }}$ Região. 2013. Agravo de Instrumento $n^{\circ}$. 19093-27.4.01.0000/PA. Relator: Desembargador João Batista Moreira. Brasília: TRF1, 12 abr. 2013.

Brasil. Secretaria-Geral da Presidência da República. 2013a. Esclarecimentos sobre a consulta aos Mundurukue a invasão de Belo Monte. Brasília:SGPR, 6 maio 2013a. Disponível em: http://www.secretariageral.gov.br/noticias/2013/05/0605-2013-esclarecimentos-sobre-a-consulta-aos-munduruku-e-a-invasao-de-belo-monte. Acesso em: 26 dez. 2019. 
Brasil. Secretaria-Geral da Presidência da República. 2013b. Governo apresenta a líderes do povo Munduruku plano de consulta sobre hidrelétricas no Tapajós. Brasília: SGPR, 26 abr. 2013. Disponível em: http://www.secretariageral.gov.br/noticias/ultimas_noticias/2013/04/26-04-2013-governo-federalreune-com-indigenas-munduruku-em-jacareacanga. Acesso em: 26 dez. 2019.

Brasil. Secretaria-Geral da Presidência da República. 2015. Secretaria Nacional de Articulação Social. Memória do processo de diálogo com lideranças munduruku. Brasília: SGPR, 24 abr. 2015.

Brasil. Superior Tribunal de Justiça. 2013. Suspensão de Liminar e de Sentença $n^{\circ} 1.745$ - PA. Relator: Ministro Felix Fischer. Brasília: STJ, 18 abr. 2013.

Brasil. Supremo Tribunal Federal. 2006. Recurso Extraordinário $n^{\circ}$ 466.343/SP. Recorrente: Banco Bradesco S/A. Recorrido: Luciano Cardoso Santos. Relator: Ministro Cezar Peluso. Brasília, 3 dez. 2006.

Canal Energia. 2015. Leilão de São Luiz do Tapajós deve sair até dezembro, diz Braga. Canal Energia, 15 abr. 2015. Disponível em: http://www.canalenergia.com.br/zpublisher/materias/Noticiario.asp?id=106029. Acesso em: 26 dez. 2019.

Carta da Ocupação de Belo Monte no 1. 2013. Vitória do Xingu: 2 mai. 2013. Disponível em: https:// ocupacaobelomonte.wordpress.com/2013/05/02/carta-da-ocupacao-de-belo-monte-numero-1/. Acesso em: 26 dez. 2019.

Carta da Ocupação de Belo Monte nº 2: sobre a pauta da nossa ocupação de Belo Monte. 2013. Vitória do Xingu: 3 maio 2013. Disponível: https://ocupacaobelomonte.wordpress.com/2013/05/03/carta-daocupacao-no-2-sobre-a-pauta-da-nossa-ocupacao-de-belo-monte/. Acesso em: 26 dez. 2019.

Carta da ocupação de Belo Monte $n^{\circ} 4$. 2013. Vitória do Xingu: 7 maio 2013. Disponível em: https:// ocupacaobelomonte.wordpress.com/2013/05/07/carta-no-4/. Acesso em: 26dez. 2019. 
Carta da ocupação de Belo Monte n ${ }^{\circ}$ 6: para a sociedade entender a nossa ocupação, a luta continua. 2013. Vitória do Xingu: 10 maio 2013. Disponível em: https://ocupacaobelomonte.wordpress.com/2013/05/10/ carta-n-6-para-a-sociedade-entender-nossa-ocupacao-a-luta-continua/. Acesso em: 26 dez. 2019.

Carta da ocupação de Belo Monte n ${ }^{\circ}$ 7: governo federal, nós voltamos. 2013. Vitória do Xingu: 27 maio 2013. Disponível: https://ocupacaobelomonte.wordpress.com/2013/05/27/carta-no-7-governo-federalnos-voltamos/. Acesso em: 26 dez. 2019.

Carta da ocupação do canteiro de Belo Monte no 8: o massacre foi anunciado e só o governo pode evitar. 2013. Vitória do Xingu: 29 maio 2013. Disponível em: https:/ocupacaobelomonte.wordpress.com/2013/05/29/ carta-no-8-o-massacre-foi-anunciado-e-so-o-governo-pode-evitar/. Acesso em: $26 \mathrm{dez} .2019$.

Carta da ocupação de Belo Monte no 9: tragédias e barragens, a luta não acaba nem lá, nem aqui. 2013. Brasília: 4 jun. 2013. Disponível em: https://ocupacaobelomonte.wordpress.com/2013/06/04/cartanumero-9-tragedias-e-barragens-a-luta-nao-acaba-nem-la-nem-aqui/. Acesso em: 26 dez. 2019.

Carta da ocupação de Belo Monte n $n^{\circ}$ 10: o governo não quer nos ouvir. 2013. Brasília: 11 jun. 2013. Disponível em: https://ocupacaobelomonte.wordpress.com/2013/06/11/carta-10-o-governo-nao-quernos-ouvir/. Acesso em: 26 dez. 2019.

Carta das Lideranças ao Ministério de Minas e Energia/Brasília. 2012. Jacareacanga: Povo Indígena Munduruku, 24 fev. 2012.

Carta do povo Munduruku ao Governo Federal. 2009. Aldeia Missão São Francisco, Rio Cururu, 12 set. 2009. Disponível em: http://ongcea.eco.br/?p=4397. Acesso em: 2 abr. 2016.

Carta do povo Munduruku ao governo federal. 2014. Disponível em: https://cimi.org.br/2014/09/36438/. Acesso em: 2 abr. 2016. 
Carvalho, G. 2013. Carta do Ministro Gilberto Carvalho, Chefe da Secretaria Geral da Presidência da República, às lideranças indígenas Munduruku. Brasília: SGPR, 7 maio 2013. Disponível em: https:// www.socioambiental.org/sites/blog.socioambiental.org/files/styles/imagem-grande/public/nsa/carta gilberto_carvalho.jpg?itok=Bsccwywo. Acesso em: 26 dez. 2019.

Clark, N. 2013a. Governo suspende estudos no Tapajós. Greenpeace, 24 jun. 2013. Disponível em: http:// www.greenpeace.org/brasil/pt/Blog/suspenso-de-estudos-d-novo-alento-ao-tapajs/blog/45703/. Acesso em: 26 dez. 2019.

Clark, N. 2013b. Juntos pelo Tapajós livre. Greenpeace, 26 abr. 2013. Disponível em: http://www. greenpeace.org/brasil/pt/Blog/juntos-pelo-tapajs-livre/blog/44975/. Acesso em: 26dez. 2019.

Comunicado ao Governo Federal. 2014. Jacareacanga: 3 nov. 2014.

Coudreau, H. 1977 [1896]. Viagem ao Tapajós. São Paulo: Universidade de São Paulo.

Cunha, M. C., e N. Farage. 1987. Caráter da tutela dos índios: origens e metamorfoses, in Os direitos dos índios. Editado por M. C. Cunha, pp. 103-117. São Paulo: Brasiliense.

Diniz, J. 2013. A nova guarda pretoriana de Dilma Rousseff. Repórter Brasil, 4 abr. 2013. Disponível em: http://reporterbrasil.org.br/2013/04/a-nova-guarda-pretoriana-de-dilma-rousseff/. Acesso em: 26 dez. 2019.

ECI. 2014. Estudo do Componente Indígena do Aproveitamento Hidrelétrico de São Luiz do Tapajós. Estudo de Impacto Ambiental, volume 22. Brasília: Eletrobras; CNEC; WorleyParsons.

Fearnside, P. 2015. Impactos nas comunidades indígenas e tradicionais, in Barragens do Rio Tapajós: Uma avaliação crítica do Estudo e Relatório de Impacto Ambiental (EIA/RIMA) do Aproveitamento Hidrelétrico São Luiz do Tapajós. Editado por L. Naka, pp. 19-30. Brasília: Greenpeace. 
Geertz, C. 1998. O saber local: novos ensaios de Antropologia interpretativa. Rio de Janeiro: Vozes.

Gluckman, M. 2009. La paz dentro de la contienda, in Costumbre y conflicto en África, pp. 32-56. Perú: Fondo Editorial Universidad de Ciencia y Humanidades.

Guizardi, M. L. 2012. Conflicto, equilibrio y cambio social en la obra de Max Gluckman. Papeles del CEIC (88):1-47.

GVCES. 2015. Projeto de São Luiz do Tapajós tem previsão de investimentos acima de 39 bilhões. GVCES, 29 maio 2015. Disponível em: http://gvces.com.br/hidreletricas-questao-ambiental-e-indigenarequer-solucao-consensual\#sthash.FsVtIAit.dpuf. Acesso em: 26 dez. 2019.

Instituto Socioambiental. 2013. Vídeo da Reunião dos Munduruku com Gilberto Carvalho. Brasília: ISA, 5 jun. 2013. Disponível em: https://www.youtube.com/watch?v=zj1Pc6yAP0Q. Acesso em: 26 dez. 2019.

Little, P. 2006. Ecologia política como etnografia: um guia teórico e metodológico.Horizontes Antropológicos 12(25):85-103. DOI: https://doi.org/10.1590/S0104-71832006000100005

Loures, R. S. P. 2017. Governo Karodaybi: o movimento IperegAyu e a resistência Munduruku. Dissertação de Mestrado, Programa de Pós-Graduação em Recursos Naturais da Amazônia, Universidade Federal do Oeste do Pará, Brasil.

MAB Amazônia. 2013. Munduruku reafirmam luta contra barragens no Tapajós. 30 abr. 2013. Disponível em: http://www.mabnacional.org.br/noticia/mundurukus-reafirmam-luta-contra-barragens-no-tapaj-s. Acesso em: 26 dez. 2019.

Manifesto Kayabi, Apiaká e Munduruku contra os aproveitamentos hidrelétricos no rio Teles Pires. 2011. Disponível em: https://www.ana.gov.br/noticias-antigas/manifesto-kayabi-apiaka-e-mundurukucontra-os.2019-03-15.0424022687. Acesso em: 09 set. 2020. 
Menéndez, M. 1992. A área Madeira-Tapajós: situação de contato e relações entre colonizador e indígenas, in História dos Índios no Brasil. Organizado por M. C. Carneiro da Cunha, p. 281-296. São Paulo: Companhia das Letras, FAPESP.

Milanez, F. 2014. Governo quer remover aldeias e alagar terra indígena para construir Usinas no Tapajós. Carta Capital, 25 set. 2014. Disponível em: http://www.cartacapital.com.br/blogs/blog-domilanez/governo-quer-remover-aldeias-e-alagar-terra-indigena-para-construir-usinas-no-tapajos-318. html. Acesso em: 26 dez. 2019.

Molina, L. P. 2017. Terra, luta, vida: autodemarcações indígenas e afirmação da diferença. Dissertação de Mestrado, Departamento de Antropologia, Universidade de Brasília, Brasília, Brasil.

Monteiro, C. 2013. Desmandos e autoritarismo marcam encontro indígena em facareacanga, sul do Pará. Belém: Conselho Indigenista Missionário, 9 ago. 2013. Disponível em: http:// cimi.org.br/site/pt-br/?system=news\&conteudo_id=7071\&action=read. Acesso em: 09 set. 2020 .

Munduruku. 2014. Protocolo de Consulta Munduruku. Aprovado em assembleia extraordinária do povo Munduruku na aldeia Sai Cinza, em 13 e 14 de dezembro de 2014. Disponível em: http://www. consultaprevia.org/\#!/documento/326. Acesso em: 7 mar. 2014.

Naka, L. Editor. 2015. Barragens do Rio Tapajós: Uma avaliação crítica do Estudo e Relatório de Impacto Ambiental (EIA/RIMA) do Aproveitamento Hidrelétrico São Luiz do Tapajós. Brasília: Greenpeace, 2015.

OIT. 1989. Convenio número 169 Sobre Pueblos Indígenas y Tribales.

Oliveira, R. 2016. A ambição dos pariwat: consulta prévia e conflito socioambiental. Dissertação de Mestrado, Programa de Pós-Graduação em Direito, Universidade Federal do Pará, Belém. 
Oliveira, R., e F. A. Vieira. 2016. Suspensão de liminar e usinas hidrelétricas: a flexibilização do licenciamento ambiental por via judicial, in Ocekadi: Violações e impactos do complexo hidrelétrico do Tapajós. Editado por D. Alarcon, B. Millikan e M. Torres. Brasília: International Rivers.

Palmquist, H. 2016. O governo que age como sucuri e a resistência dos Munduruku às barragens no Tapajós, in Ocekadi: Violações e impactos do complexo hidrelétrico do Tapajós. Editado por D. Alarcon, B. Millikan e M. Torres. Brasília: International Rivers.

Santana, R. 2013a. Caciques e lideranças Munduruku denunciam intervenção do governo federal para forçar construção de usina. Brasília: Conselho Indigenista Missionário, 9 ago. 2013. Disponível em: http:// www.cimi.org.br/site/pt-br/index.php?system=news\&action=read\&id=7073. Acesso em: 24 mar. 2016.

Santana, R. 2013b. Governo quebra acordo com povo Munduruku e inicia operação militar no Pará. Brasil de Fato, 13 ago. 2013. Disponível em: http://www.brasildefato.com.br/node/17781. Acesso em: 24 mar. 2016.

Silva, C. 2011. O refém cordial. Blog do Arnaldo. Disponível em: http://oglobo.globo.com/blogs/ arnaldo/posts/2011/10/31/sociologo-servico-do-governo-refem-de-indios-faz-relato-corajoso-413881. asp. Acesso em: 26 dez. 2019.

Silva, R. F. A. M. 2014. Parecer Pericial nº 01/2014. Santarém: Ministério Público Federal.

Sposati, R. 2013a. Belo Monte: nova ocupação, mesmas demandas, mesmos problemas. Altamira: Movimento Xingu Vivo para Sempre, 28 maio 2013. Disponível em: http://www.xinguvivo.org.br/2013/05/28/belomonte-nova-ocupacao-mesmas-demandas-mesmos-problemas/. Acesso em: 25 dez. 2019.

Sposati, R. 2013b. Munduruku queimam proposta do governo federal sobre consulta prévia. Jacareacanga: Brasil de Fato. Disponível em: https://www.brasildefato.com.br/node/12779/. Acesso em: 25 dez. 2019. 
Sposati, R. 2013c. "Não estamos indo a Brasília negociar", afirmam indígenas. Altamira: Conselho Indigenista Missionário, 4 jun. 2013b. Disponível em: https://cimi.org.br/2013/06/34880/. Acesso em: 24 mar. 2016.

Tocantins, A. M. G. 1877. Estudos sobre a tribu "mundurucu”. Rio de Janeiro: Instituto Histórico Geographico e Ethnographico do Brasil.

Valle, R. 2013. Operação Tapajós: “Os Munduruku não querem guerra”. Entrevista ao Portal IHU Online. IHU Online, 7 abr. 2013.

Vianna, A. 2014. Etnografando documentos: uma antropóloga em meio a processos judiciais, in Antropologia das práticas de poder: reflexões etnográficas entre burocratas, elites e corporações. Editado por S. R. R. Castilho, A. C. S. Lima e C. C. Teixeira, pp. 43-70. Rio de Janeiro: Contra Capa.

Von Ihering, R. 1907. As cabeças mumificadas pelos índios mundurucús. Revista do Museu Paulista7:179-201.

Yahoo. 2015. EPE identifica potencial para construção de 25 novos projetos hidrelétricos. Yahoo, 27 maio 2015. Disponível em: https://br.financas.yahoo.com/noticias/epe-identifica-potencial-constru\% C3\%A7\%C3\%A3o-25-155000449.html. Acesso em: 26 dez. 2019. 